\title{
The Effectiveness of Use of the Sidoarjo Peoples's Service System (SIPRAJA) in Improving Public Servicesin Tambakrejo Village, Waru District, Sidoarjo Regency
}

\author{
Aprilia Devi Rekasari ${ }^{1, *}$ Eva Hany Fanida ${ }^{2}$ \\ 1,2 Department of Public Administration, Universitas Negeri Surabaya \\ ${ }^{*}$ Corresponding author. Email: aprilia.18002@mhs.unesa.ac.id
}

\begin{abstract}
The Sidoarjo People's Service System (SIPRAJA) is an innovation created by the Sidoarjo Regency Government in improving the quality of public services. This is done by the Tambakrejo Village Government in using the Sidoarjo People's Service System (Sipraja) which is expected to be able to provide effective services to the community. The purpose of this study is to describe the effectiveness of using Sipraja in improving public services in Tambakrejo Village. This study uses a qualitative method that seeks to explore oral data through the interview process, written data through observations on documents. The analysis of this study uses sixindicators which include human resources, system quality, information quality, service quality, user satisfaction and net benefits. The conclusion of this study shows that Sipraja service in Tambakrejo Village can be considered effective, because the system is able to reduce the duration of bureaucratic time in various community needs and administering permits. However, there are still several factors that hinder the effectiveness of Sipraja services, namely; 1) Lack of understanding about the technicalities of Sipraja; 2) Lack of in-depth socialization from the village government to the community regarding Sipraja. Referring to these advantages and obstacles, Sipraja is expected to continue to be addressed and developed to be able to provide more effective services to the community.
\end{abstract}

Keywords: Effectiveness, Public Service, Sipraja

\section{INTRODUCTION}

Public service is one of the benchmarks in the success of the wheels of government in providing services to the community. Law Number 25 of 2009 concerning Public Services states that public services are activities or series of activities in the context of fulfilling service needs in accordance with laws and regulations for every citizen and resident of goods, services, and/or administrative services provided by public service providers [1].
Of course, this is related to the role of the government as a service provider to improve the quality of its services to the community. The government is a public service provider who must be responsible for the community and continue to strive for quality services [2]. The government as a public service provider must pay attention to the needs and interests of service users. How these services can be enjoyed and in accordance with the needs of the community [3]. Thus the quality of public services will be better and in accordance with the 
objectives. In addition, this is also to minimize misunderstandings between the government as a service provider and the community as service users [4].

Efforts to accelerate the realization of good governance are by improving the quality of public service delivery. The basic form of government itself is to realize the welfare and happiness of the community, through public services [5]. It is undeniable that along with the development of the era by making everything easier with technology, the community expects a change in service so that it is optimal in providing services to the community [6]. The rise of technology used and growing day by day, it is time for technology to be used as a medium for public services [7]. Local governments are the closest public service providers to the community, so local governments are required to make improvements in carrying out their service roles. However, ironically, it is still found that the performance of the government is still considered less than optimal due to the low performance of the bureaucratic apparatus [8].

Bureaucratic services that are less than optimal for the public, lead to a perception from the public that the bureaucracy does not work optimally as a public servant. It is unfortunate that the quality of personnel resources in Indonesia is still low. The current phenomenon shows that district integrated administrative services still require improvement or development, especially at the level of apparatus performance [9]. The existence of a work culture that is less productive, the resulting performance will definitely be unsatisfactory [10]. Unsatisfactory performance is caused by low levels of availability, substandard quality of information, unreliable government services, and vulnerabilities in information security [11].

One form of government in providing services to the community is population administration services. Population administration services are a series of structuring and publishing activities in the issuance of population documents and data through population registration, civil registration, population information management and utilization of the results for public services and other sector development [12].

The population administration service still has many obstacles in its implementation. Many people still feel that they are not satisfied with the performance of service providers. Problems related to population administration according to data from the 2019 RI Ombudsman report, there were 249 reports which showed that population administration was one of the substances that had the highest number of reports. And the most regional complaints reported to the Indonesian Ombudsman for East Java Representatives in 2019 were Sidoarjo Regency with as many as 15 reports.

From the existing public service problems, the Sidoarjo Regency Government seeks to make changes in improving the quality of existing public services. Efforts made by the Government of Sidoarjo Regency are by distributing government services to the community. This then became the basis and development of the Sidoarjo Regency Government to improve the existing public service system by implementing services with electronic government at every public service provider agency. An effective way to meet customer needs is to utilize smart government features with technology applications so that the effectiveness and ability to offer improved public services to customers [13]. Electronic government is a new interaction mechanism between the government and the community and other interested parties, involving the use of information technology (especially the internet) with the aim of improving the quality (quality) of services [14].

By switching to an online-based system, the Sidoarjo Regency Government hopes to provide even distribution of services to the community. So that the goal of the Sidoarjo Regency Government in providing optimal services can be realized. Excellent and fast service has an impact on community satisfaction. Meanwhile, poor, slow service makes people dissatisfied and has an impact on irritation and worsens the government as a public servant [15].

Another factor that underlies the Sidoarjo Regency Government to take steps to make online-based public service innovations is caused by public complaints that the service is not effective and efficient. This is because the procedures and queues are long and disorganized. In addition, the process of administrative processing using a manual system takes a long time, and is at risk of writing errors in public data [16].

The Sidoarjo Regency Government created an innovation for population administration services in an android application, namely the Sidoarjo People's Service System (Sipraja) which aims to make it easier for the community to take care of letters and population administration needs in the village, and sub-district work areas. With this Sipraja innovation, it is expected to be able to answer the needs of the people of Sidoarjo which ensures the process is faster, easier, cheaper, and satisfying the residents. The emergence of the Sipraja application is motivated by the assumption that government services are complicated, slow, expensive, uncertain, and tiring [17] [18]. The existence of Sipraja was warmly welcomed by village/kelurahan officials and implemented as an official village/kelurahan system [19].

The application of Sipraja as an electronic government-based service in Tambakrejo Village is expected to be able to facilitate services to the community, so as to answer various problems related to public services that have been complained of by the community by minimizing the occurrence of things that are out of control such as the creation of a letter which 
takes a long time. , there was a writing error and a long queue at the village office.

The implementation of Sipraja based on electronic government is quite successful in Tambakrejo Village. However, what is the level of effectiveness of public services that can be produced through this service system in answering existing problems and still needs to be proven and researched. This is what underlies the author to conduct research with the title "Effectiveness of the Use of the Sidoarjo People's Service System (Sipraja) in Improving Public Services in Tambakrejo Village, Waru District, Sidoarjo Regency"

\section{METHODS}

The type of research used in this research is descriptive research with a qualitative approach. Descriptive research with a qualitative approach is used to answer questions from the problems to be studied by providing an overview in the form of clear data regarding the problems studied. The focus of this research refers to using six indicators of effectiveness which include human resources, system quality, information quality, service quality, user satisfaction and net benefits.

The six indicators of effectiveness in this study are intended as a descriptive explanation of the role and function of the Sidoarjo People's Service System (Sipraja) as a process that can work in accordance with the stated objectives or not. This research was conducted in Tambakrejo Village, J1. Raya Tambakrejo RT. 01 RW. 08 No. 01, Waru District, Sidoarjo Regency. There are three data collection techniques used, namely observation, interviews, and documentation. While the data analysis technique uses the Miles and Huberman interactive model cited by Sugiyono (2018), namely data collection, data processing, data presentation and drawing conclusions [20].

\section{RESULTS AND DISCUSSION}

The type of research used in this research is descriptive research with a qualitative approach. Descriptive research with a qualitative approach is used to answer questions from the problems to be studied by providing an overview in the form of clear data regarding the problems studied. The focus of this research refers to using six indicators of effectiveness which include human resources, system quality, information quality, service quality, user satisfaction and net benefits.

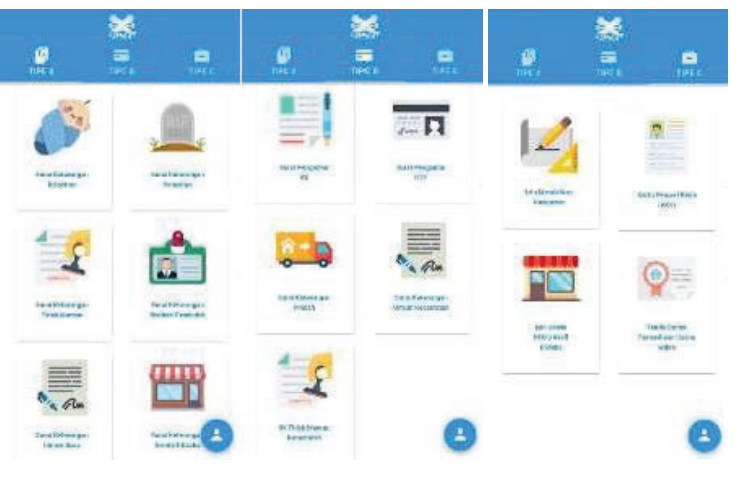

Figure 1 Sipraja Menu Display

The application of Sipraja in the Tambakrejo village government aims to improve the quality of service to the community. By utilizing technology, it is hoped that it can provide services to the community quickly and accurately. To find out the extent of the effectiveness of the implementation of Sipraja in Tambakrejo Village, Waru District, Sidoarjo Regency, researchers used six indicators of the effectiveness of a service system which include:

\subsection{Human Resources}

Human resources are one of the factors used as a benchmark in assessing the effectiveness of a service system. The ability of village employees to run Sipraja is very much needed because this system is different from the previous system used in Tambakrejo Village. So we need employees who have the ability and competence related to the management of Sipraja.

Tambakrejo Village employees who become operators are expected to be able to provide good performance and in accordance with what is determined by the Village Government, such as providing fast service to the community, so that they can meet the needs of the community regarding mail processing services. It is the operator's duty to demonstrate their performance and competence as good Sipraja managers.

In forming human resources who are competent in operating Sipraja, the Tambakrejo Village Government cooperates with the Sidoarjo Regency Government in conducting socialization and technical guidance training related to the use of Sipraja. The training and socialization was attended by 120 participants, consisting of $76 \mathrm{RT}$ parties, $14 \mathrm{RW}$ parties, besides that there were also local community institutions. The implementation of the technical guidance and socialization training brought in sources for the makers and managers of the Sipraja center. In this activity, technical guidance participants were trained on the stages in operating the Sipraja application, starting from the web address, the registration process, to the stages of managing letters. 
Referring to the indicators of human resources, in addition to competence, commitment from the service provider is also needed. The commitment of the employees is quite good. This can be seen from the performance of the operators who are really serious in serving the residents. The operators continue to serve the community even though it is not working hours because Sipraja can be accessed online. Commitment from service providers is also very influential on the effectiveness or not of a system used in serving the community.

\subsection{Quality Service System}

The ease of accessing the service system is a measure of the quality of the service system, which can be said to be good or not. In its use, the public must be facilitated in accessing the service system so that user satisfaction is met. If the satisfaction of the community can be met, the quality of the service system can be said to have good and qualified quality. The management of Sipraja in Tambakrejo Village can be said to be quite good by having various features in managing letters needed by the community.

Sipraja was implemented in Tambakrejo Village in early July 2020. Although it is still running for 1 year, the implementation can be said to be going well and in accordance with the objectives. This is shown by the response from the surrounding community who have used the Sipraja application. They feel very facilitated in the management of the letter. Because Sipraja can be accessed through an Android-based application that can be downloaded from the app store and a website that can be accessed via https://sipraja.sidoarjokab.go.id. This Sipraja application can be accessed anywhere, anytime and only requires an internet connection to access it. So that people find it easy to use.

In practice, the Tambakrejo Village Government is responsive in carrying out Sipraja. This is done by the village because the services provided can be focused and can run effectively and efficiently. So that the Tambakrejo Village government can provide the best possible service to the community. The Village Information System was created to provide fast and precise public services.

\subsection{Information Quality}

The quality of information is a factor in determining a service system can be said to be effectively used or not. This can be seen by how the service system can provide information regarding what is needed in the management of the required letters.

The Sipraja application is equipped with features that are in accordance with the needs of the community. In the Sipraja application there is already information related to the management of the letter. This is very helpful for the community in knowing what to prepare when making the required letter. In the previous service, the community had to come to the village office to find out what to prepare. So the community had to come to the village office many times and it took quite a long time. With the use of Sipraja, people just need to open Sipraja through the website or application that can be downloaded on the Playstore.

The data above shows that the use of Sipraja in Tambakrejo Village is running effectively, and is very helpful for the community in obtaining public services. There is a comparison between the previous and current service periods which shows that the current service is very fast and responsive in serving the community. The people of Tambakrejo Village feel that it is easier to get information and services by using Sipraja.

\subsection{Quality of Service}

Services that have quality are services that are updated with the times and can meet the needs of users. Operators/employees are parties that control services so they must have quality competence in controlling computers and so on to support their performance. This is to measure the quality of services provided to the community. Service quality can also be measured from the behavior of service providers, whether in providing services to the community it is in accordance with applicable regulations.

At Sipraja, operators are always responsive in providing information and verifying letters made by the public. The Tambakrejo Village Government implements Sipraja in order to be able to provide services to the community quickly and precisely, thus facilitating and expediting everything related to the needs of community letters. This proves that the Tambakrejo village government provides better services by serving the community quickly and with public service standards that are in accordance with what the community wants. This is very different from the previous system implemented by the Tambakrejo village. Now the service in Tambakrejo Village is much better in terms of governance and public services.

The implementation of good public services is the main task for the government because it is the duty of the government as a provider of community needs. The Tambakrejo Village Government has been able to do this by providing ideal services to the community.

\subsection{Consumer Satisfaction}

A service system can be said to work effectively if the users of the service system feel satisfied and helped. The community as recipients of public services will be able to feel how the service system works. The government's obligation as a government administrator who has the task of providing public services is indeed supposed to prepare and provide the best needs in serving the community. 
The implementation of Sipraja in Tabakrejo Village is one of the efforts of the Tambakrejo Village Government to be able to provide effective services to the community. So that Tambakrejo Village can easily carry out its duties as a service provider to the community. The use of Sipraja, in Tambakrejo Village, was very enthusiastically welcomed by the community. The reason is, before the existence of Sipraja, when people were going to take care of their letters they had to queue and wait for quite a long time. However, after Sipraja, people who want to take care of letters can simply use their cellphones and are at home, letters can be made.

From the research conducted, it shows that the Tambakrejo Village Government as the organizer of government in the village has taken the right steps in improving public services, so that it can provide a sense of satisfaction to the community. With this, the community hopes that the Tambakrejo Village Government is able to maintain its performance in making the community satisfied regarding the services provided.

\subsection{Net Benefit}

Service systems that can be said to be effective in their use are services that have advantages in their use. When the service system is implemented and produces profits that are in line with expectations, the performance of the service system can be assessed as effective. Because it produces something as planned. So that the government as a service provider can carry out government administration well.

The existence of Sipraja in Tambakrejo Village which benefits the most is that the village government is very helpful in providing services to the community quickly and precisely. The implementation of Sipraja in Tambakrejo Village can be considered to be running well and produce net benefits that are in line with expectations, which are very helpful in the implementation of public services. With the fast and appropriate service, the community is satisfied with the services provided by the Tambakrejo Village government. Another advantage is that the Tambakrejo Village government can run public services in accordance with the times.

The Sidoarjo People's Service System (Sipraja) has a very positive impact on Tambakrejo Village. This can be seen from the changes that occur related to services. By using Sipraja, the service which was originally still manual is now more practical and can be accessed online. So that the public services in Tambakrejo Village are very productive in serving the community.

\section{CONCLUSION}

The implementation of Sipraja in Tambakrejo Village is one of the village government's efforts in providing convenience to the community in getting services to take care of making a certificate at the village office. Based on the analysis that has been done, it can be concluded that the Sidoarjo People's Service System (Sipraja) has been running effectively even though it is still running in 1 year. The effectiveness of the implementation of Sipraja in Tambaktejo Village is supported by 6 indicators, namely human resources, system quality, information quality, service quality, user satisfaction and net benefits.

Although the implementation is considered to have been running effectively, there are still obstacles, namely there are still people who do not understand and know about services using Sipraja. So there are still many people who come to the village office to make the required letters. Therefore, the Tambakrejo village government should hold a more in-depth socialization to the community so that the community can know the use of Sipraja.

\section{REFERENCES}

[1] Law of the Republic of Indonesia Number 25 of 2009 concerning Public Services

[2] Rukayat, Y.Quality of Public Service in the Field of Population Administration in Pasirjambu District. Scientific Journal of Masters in Administrative Sciences (Jimia).2017, 2, 56-65.

[3] Ibrahim, Ahmad Nazrul Hakimi \& Borhan, Muhamad \& Zakaria, Nur \& Zainal, Siti.Effectiveness of Commuter Rail Service Toward Passenger's Satisfaction: a Case Study from Kuala Lumpur, Malaysia. International Journal of Engineering and Technology. 2019. 8. 50-55. http://dx.doi.org/10.14419/ijet.v8i1.2.24871

[4] Andrews, R., Beynon, M., \& Genc, E. Strategy Implementation Style and Public Service Effectiveness, Efficiency, and Equity. 2017. Administrative Sciences, 7 (1), 4. https://doi.org/10.3390/admsci7010004

[5] Ziadi, A. R., Supriyono, B., \& Fefta Wijaya, A. (n.d.). International Journal of Management and Administrative Sciences (IJMAS) The Effectiveness Of Information System In Public Complaint Service: An Implementation Of EGovernment Based On Jakarta Smart City Applications.

2016. https://dx.doi.org/10.2991/icaspgs-icbap17.2017.18

[6] Paat, Harry P., Grace B. Nangoi, And Rudy J. Pusung. "Effectiveness And Efficiency Analysis For The Budgeting Implementation In.”. 2019. 7(3): 2979 
[7] Suharta, R., \& Firdausi, F. The Effectiveness of Kelurahan Information System (Sik) in Improving Public Services (Study on Sisir Village, Batu City). 2019. $8(2)$ https://doi.org/10.33366/jisip.v8i2.1718

[8] Luas, J., Kimbal, M., \& Singkoh, F. (N.D.). Effectiveness of Public Services in Kakaskasen Dua Village, North Tomohon District, Tomohon City. 2017.

http://ejournal.unsrat.ac.id/index.php/jurnaleksekut if/article/view/18400/17928

[9] Tahili, Mashuri H.The Effect of Public Service Motivation on Integrated Administration Services at District Level of Government. International Journal of Administrative Science \& Organization. 2018. (Vol. 25, Number 2). https://doi.org/10.20476/jbb.v25i2.9827

[10] Natalia, J. The Effectiveness of Employee Services in the Level of Community Satisfaction at the Jawa Village Office, Samarinda Ulu District. 2021(2), 125-136.

[11] Sabani, A., Deng, H., \& Thai, V. Evaluating the performance of e-government in Indonesia: A thematic analysis. ACM International Conference Proceeding Series, Part F148155, 2019. 435-440. https://doi.org/10.1145/3326365.3326422

[12] Wahyono Suko, Budi Prihatminingtyas, Annisa Purwatiningsih. Implementation of Malang City Population Administration Services. Tribhuwana Tunggadewi University. 2019. https://doi.org/10.52166/madani.v11i1.1352

[13] Saeed, H., \& Alkuwaiti, A. Scholarworks @ UAEU. Effectiveness of the Smart Government in Abu Dhabi Municipality: A Study of the Customers' Opinion United Arab Emirates University College of Humanities and Social Sciences Department of Government and Society Effectivenes Of The SM. 2020.

https://scholarworks.uaeu.ac.ae/all_theses/747

[14] Indrajit, Richardus Eko. 2002. Membangun Aplikasi E-Government. Jakarta: PT Elek Media Komputind

[15] Case, S., Sidorejo, D., Bandongan, K., Magelang, K., Rihardi, S. A., Yusliwidaka, A., \& Mazid, S. Effectiveness of Government in Public Services With Sikdes (Village Connectivity Information System). In JPALG. 2019. (Vol. 3, Issue1).http://jurnal.untidar.ac.id/index.php/publicd mini. http://dx.doi.org/10.31002/jpalg.v3i1.1362

[16] Rahmawati, L., Umi Ati, N., \& State Administration, J. The Effectiveness of Public
Services in the Field of Population Administration During the Covid-19 Pandemic (Case Study in Samaan Village, Klojen Subdistrict, Malang City). 2021. (Vol. 15, Issue 9). http://riset.unisma.ac.id/index.php/rpp/article/view/ $12411 / 0$

[17] https://www.sidoarjokab.go.id/sipraja-sistempelayan-sidoarjo accessed on October 3, 2021

[18] https://www.sidoarjokab.go.id/bupati-sidoarjolaunching-sipraja-jasa-online-android-levelkecamatan-dan-Desakelurahan accessed on October 3, 2021

[19] https://www.sidoarjokab.go.id/bupati-sidoarjolaunching-sipraja-jasa-online-android-levelkecamatan-dan-Desakelurahan accessed on October 3, 2021

[20] Sugiyono. 2018. Quantitative, Qualitative, and R\&D Research Methods. Bandung: Alphabeta 